\title{
北海道東部サロマ湖周辺域における 10〜17 世紀の海水準変動
}

\author{
添田雄 二*・赤 松 守 雄*
}

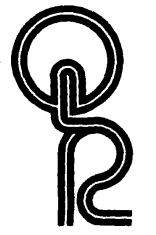

北海道東部のサロマ湖周辺域において, 摩周 b 火山灰 $(\mathrm{Ma}-\mathrm{b}:$ 約 970 年噴火) と駒ヶ岳 $\mathrm{c} 2$ 火山 灰(Ko-c2: 1694 年噴火)の間の堆積物を採取し, 珪藻遺骸分析による古環境復元を試みた. その 結果, 全般的に淡水生種が多産するが, 海水 汽水生種の出現率の層位的変化から, 10 世紀末 11 世紀と 14 世紀末〜 16 世紀末の 2 回の塩分濃度上昇期の存在が明らかになった. $10 〜 17$ 世紀に おけるこの塩分濃度変動は, 気候变化にとあなう海進・海退のサイクルに対応している可能性が 高い.

\section{キーワード : オホーツク海, サロマ湖, 珪藻, テフラ, 海水準変動}

\section{I. は じめに}

日本列島およびサハリンには, 日本海, オホーツク海 という2つの縁海が存在する. そのうち, オホーツク海 は北半球における結水域の南限であり, 環境変化に最も 敏感に反応する海域として知られている. オホーツク海 へは, 日本海を北上する対馬暖流の一部が宗谷暖流之 して宗谷海峡から流入する. そのため, 対馬暖流の強弱 は, 日本海はもとよりオホーツク海の海況や同地域の気 候にも多大な影響を与えることが明らかにされている （赤松・右代, 1995). また, 北海道のオホーツク海沿岸. 域は, 最む荒天となる冬の間, 流水が海岸部を保護する ために，完新世以降の海水準変動を反映した砂丘や海跡 湖などか数多くみられる(磯部ほか入，1999）.

近年, 北海道とサハリンのオホーツク海沿岸域では, 貝塚の古環境解析や海底堆積物および沖積平野構成層の 珪藻遺骸分析, さらに湖沼周辺の微地形による検討など から, 平安海進期(中世温暖期)の存在が明らかにされて いる(平井, 1987, 1994 ; 赤松-右代, 1995 ; 児平, 1996 ; 赤松ほか, 1998 ; 嶋田ほか, 2000). また, 日本海南部お よびサロマ湖におけるボーリング資料(貝類)の ${ }^{14} \mathrm{C}$ 年代 值ならびに極東ロシアおよびサハリン南部に生息する貝 類(温暖水系種)などの分析から，15 世紀前後の温暖期の 存在が報告されている(赤松・右代, 2000). 一方, 沢
井・三塩(1998)は，厚岸湖北方の別唭辺望湿原における 珪藻遺骸分析汃ら, 約 3,000 年前以降の相対的海水準变 動と古環境の変遷を 3 つのステージに区分している. そ のうち，ステージ 3(900 yrs BP〜現在)では約 600 年前 以降に小規模な海進がみられたが, 約 300 年前頃から海 退に転じ，現在の湿原か形成されたとしていいる。

本稿では, 北海道東部の 10 世紀以降におけるより詳 細な古環境の知見を得ることを目的として，サロマ湖周 辺域で採取した堆積物の珪藻遺骸分析から, 10 世紀以降 における海水準変動の復元を試みた.

\section{II. 調査地の指標テフラと地質層序}

珪藻遺骸分析による古環境復元を行うため, サロマ湖 南西岸に流入する計呂地川および琶露川河口付近の低地 で, 掘削により堆積物を採取した(図 1). 地点 1 は, 計呂 地川の河口から約 $500 \mathrm{~m}$ 上流域に広がる標高約 $0.8 \mathrm{~m}$ の低湿地である. 地点 2 は, 芭露川河口から約 $200 \mathrm{~m}$ 東 方に位置する標高約 $0.8 \mathrm{~m}$ の湖岸低地(湖から約 $20 \mathrm{~m}$ 陸側)である. 地点 1 付近における川の水質は淡水, 地点 2 付近における湖の水質は汽水(塩分濃度 15〜20\%)であ る.

北海道北東〜東部に分布する完新世テフラについて は, 遠藤ほか(1989,1996a), 町田ほか(1994), 徳井 (1995)などによって総括されている.それらによれば, 


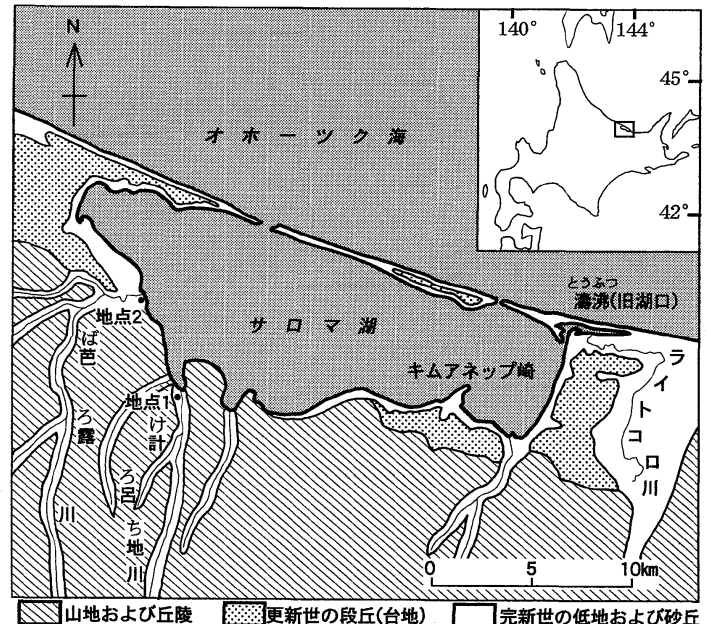

図 1 調 查 地 域 地形区分は平井(1994)による.

上位から樽前 $\mathrm{a}(\mathrm{Ta}-\mathrm{a}: 1739$ 年), 駒ヶ岳 $\mathrm{c} 2(\mathrm{Ko}-\mathrm{c} 2$ : 1694 年), 摩周 b(Ma-b : 約 970 年, 勝井, 1996), 白頭 山苫小牧(B-Tm : 10 世紀前半, 福澤ほ力, 1998 ; 早川・ 小山, 1998), さらに下位には樽前 $\mathrm{c}(\mathrm{Ta}-\mathrm{c}:$ 約 3,000 年 前)が分布する.

堆積物を採取した地点 1,2 では, 地表から約 $90 \mathrm{~cm}$ の間に層厚 2 3 cm のテフラを 3 枚確認することがで きた. 両地点における上・中・下位のテフラは, 大半が 軽石型の火山ガラスから構成され, 若干の石英や輝石を 含んでいる. 肉眼観察ではそれぞれがよく似ており, 上 位のテフラは黄白色細粒パミス(粒径 0.1 0.2 mm), 中 位のテフラは灰白色細粒パミス(粒径 $0.1 \sim 0.2 \mathrm{~mm}$ ), 下 位のテフラは黄白色細粒〜中粒パミス（粒径 $0.2 \sim 0.5$ $\mathrm{mm}$ )であった.これらの対比を目的とし，3枚のうち中 位抢よび下位のテフラの火山ガラスについて, 北海道大 学の EDAX 社製 PV 9100 型 EDS を用いて主成分化学 分析を行った. また, 北海道南部の江差町と東部の弟子 啒町で記載(遠藤ほか, 1996b; 町田, 1996)されている歴 史時代の各テフラを採取して同様に分析し, 前述した地 点 1,2 のテフラととあに, それらの $\mathrm{CaO}, \mathrm{FeO}, \mathrm{TiO}_{2}$, $\mathrm{K}_{2} \mathrm{O}$ の含有率の関係を比較・検討した. 分析結果は表 1 のとおりである. この結果から, 地点 1,2 で確認された 3 枚のテフラのうち, 下位のテフラが $\mathrm{Ma}-\mathrm{b}$, 中位のテ フラが Ko-c2 であると考えられる. 上位のテフラは, 層 位関係加 $\mathrm{Ta}-\mathrm{a}$ 之推定した。

次に, 地点 1 で観察された地質層序は, 深度 $13 \mathrm{~cm}$ ま でが泥炭で, 深度 3〜 $5 \mathrm{~cm}$ および $8 \sim 10 \mathrm{~cm}$ にそれぞれ
表 1 火山ガラスの主成分分析結果

\begin{tabular}{|c|c|c|c|c|}
\hline $\begin{array}{l}\text { 採取地 成分 } \\
\text { およびテフラ }\end{array}$ & $\mathrm{CaO}$ & $\mathrm{FeO}$ & $\mathrm{TiO}_{2}$ & $\mathrm{~K}_{2} \mathrm{O}$ \\
\hline 地点1: 下位 $($ 深度約 $70 \mathrm{~cm})$ & 2.21 & 1.58 & 0.39 & 0.63 \\
\hline 地点 $2:$ 下位 $($ 深度的 $85 \mathrm{~cm})$ & 2.46 & 1.66 & 0.40 & 0.68 \\
\hline 地点1: 中位(深度約 $10 \mathrm{~cm}$ ) & 1.73 & 1.17 & 0.29 & 1.80 \\
\hline 地点 $2:$ 中位(㳭度的 $35 \mathrm{~cm}$ ) & 1.82 & 1.14 & 0.20 & 1.80 \\
\hline 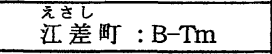 & 1.32 & 4.32 & 0.29 & 5.23 \\
\hline 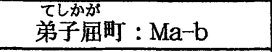 & 2.25 & 1.66 & 0.47 & 0.72 \\
\hline 弟子屈町 : Ko-c2 & 1.79 & 1.18 & 0.29 & 1.82 \\
\hline
\end{tabular}

各元素は酸化物の形で表現. 値はすべて平均値 (分析試料数は各 10 点).

Ta-a と Ko-c2 か認められる. 深度 $13 \sim 68 \mathrm{~cm}$ はシルト で, 深度 37.5 43 cm および $47 \sim 49 \mathrm{~cm}$ には黒みの強い 分解質泥炭が挾在する. 最下部の深度 $68 \sim 70 \mathrm{~cm}$ は $\mathrm{Ma}-$ $\mathrm{b}$ であった(図 2). また，地点 2 で観察された地質層序 は, 深度 $7 \mathrm{~cm}$ までが泥炭, 深度 9 12 cm がシルトで, それらの間の深度 7 9 cm に Ta-a が認められる. 深度 12 85 cm は細〜中粒砂(深度 $12 \sim 28 \mathrm{~cm}$ : 細〜中粒砂, 深度 $28 \sim 35 \mathrm{~cm}$ : 細粒砂, 深度 $44 \sim 60 \mathrm{~cm}$ : 細粒砂, 深度 $60 \sim 74 \mathrm{~cm}$ : 細 中粒砂, 深度 $76 \sim 85 \mathrm{~cm}$ : 細粒砂)で, 深 度 35〜37 cm に Ko-c2 か認められる．また，深度 37〜 $44 \mathrm{~cm}$ および深度 $74 \sim 76 \mathrm{~cm}$ に分解質泥炭力挾在する. 最下部の深度 85〜 $88 \mathrm{~cm}$ は $\mathrm{Ma}-\mathrm{b}$ である(図 3).このよ うに，地点 1 ではシルトが，地点 2 では砂(細粒および 細〜中粒)がそれぞれ卓越する.

\section{III. 珪藻遺骸分析}

地点 1,2 において, 表層から $\mathrm{Ma}-\mathrm{b}$ までを掘削し, 幅 $10 \mathrm{~cm}$, 奥行 $6 \mathrm{~cm}$ ほどのプラスチック製ケースを地層断 面に直接押し当て堆積物を連続ではぎ取った. 分析試 料は，はぎ取った堆積物から厚さ $5 \mathrm{~mm}$ ずつ連続して採 取した. 珪藻遺骸の抽出方法は次のとおりである. 試料 から約 $0.2 \mathrm{~g}$ を取り, 有機物の除去と堆積物の拡散のた め, $15 \%$ 過酸化水素水で処理した. さらに, 蒸留水を加 えて放置した後, 上澄みを捨てる作業を $2 \sim 3$ 回繰り返 し，粘土粒子などを除去した，残った懸濁液に蒸留水を 加えて $50 \mathrm{ml}$ とした後, $0.25 \mathrm{ml}$ をマイクロピペットで 取り, カバーグラス上に滴下した. 乾燥後, マウント メディア(和光純薬)でスライドグラスに貼りつけ, プレ パラートとした．検鏡は倍率を $1,000 \sim 1,500$ 倍にし，そ れぞれ 250 凯について計数を行った. Ko-c2 から Ma-b 


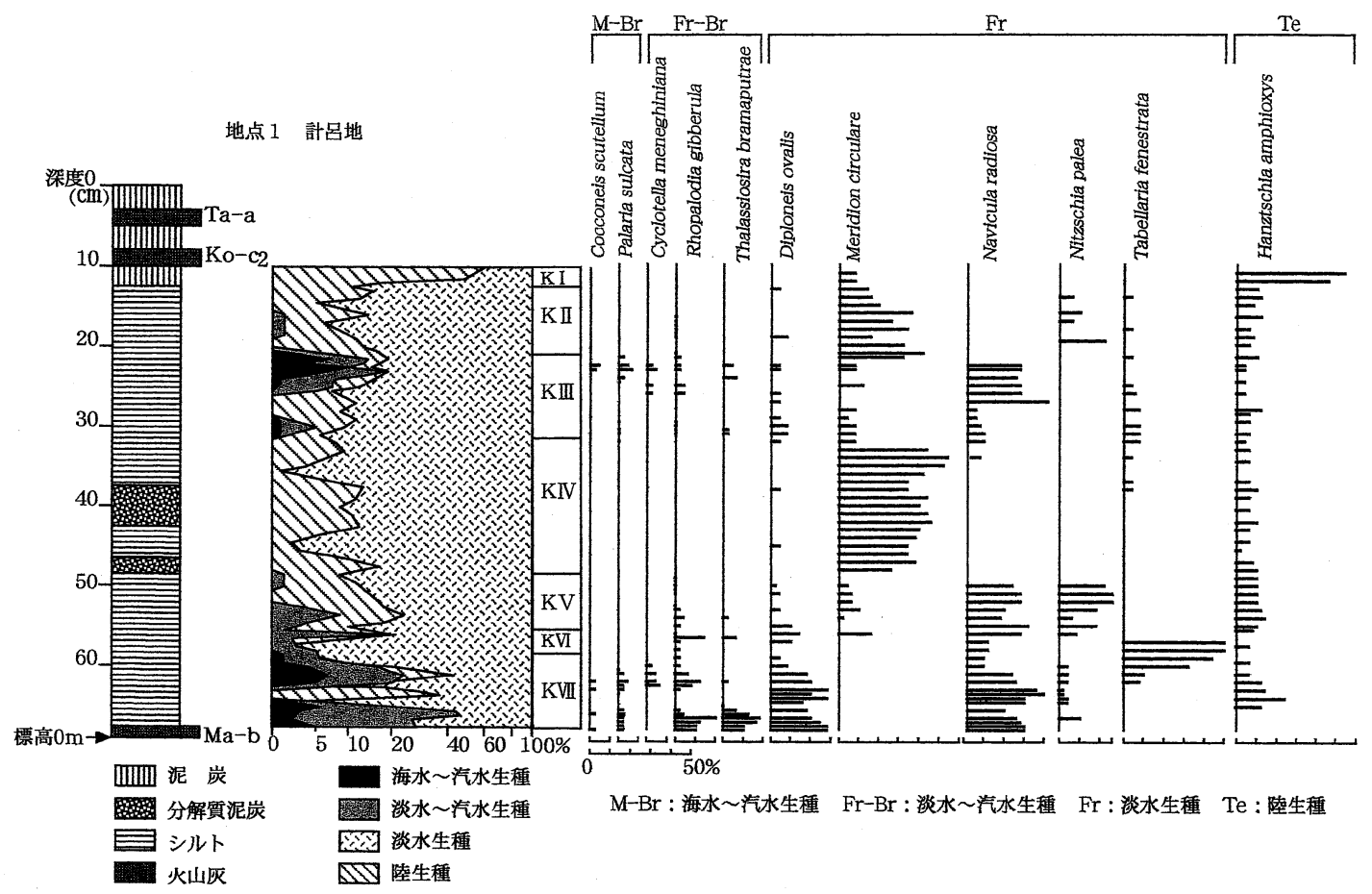

図 2 計呂地(地点1)に打ける地質柱状図と珪藻遺骸分析結果

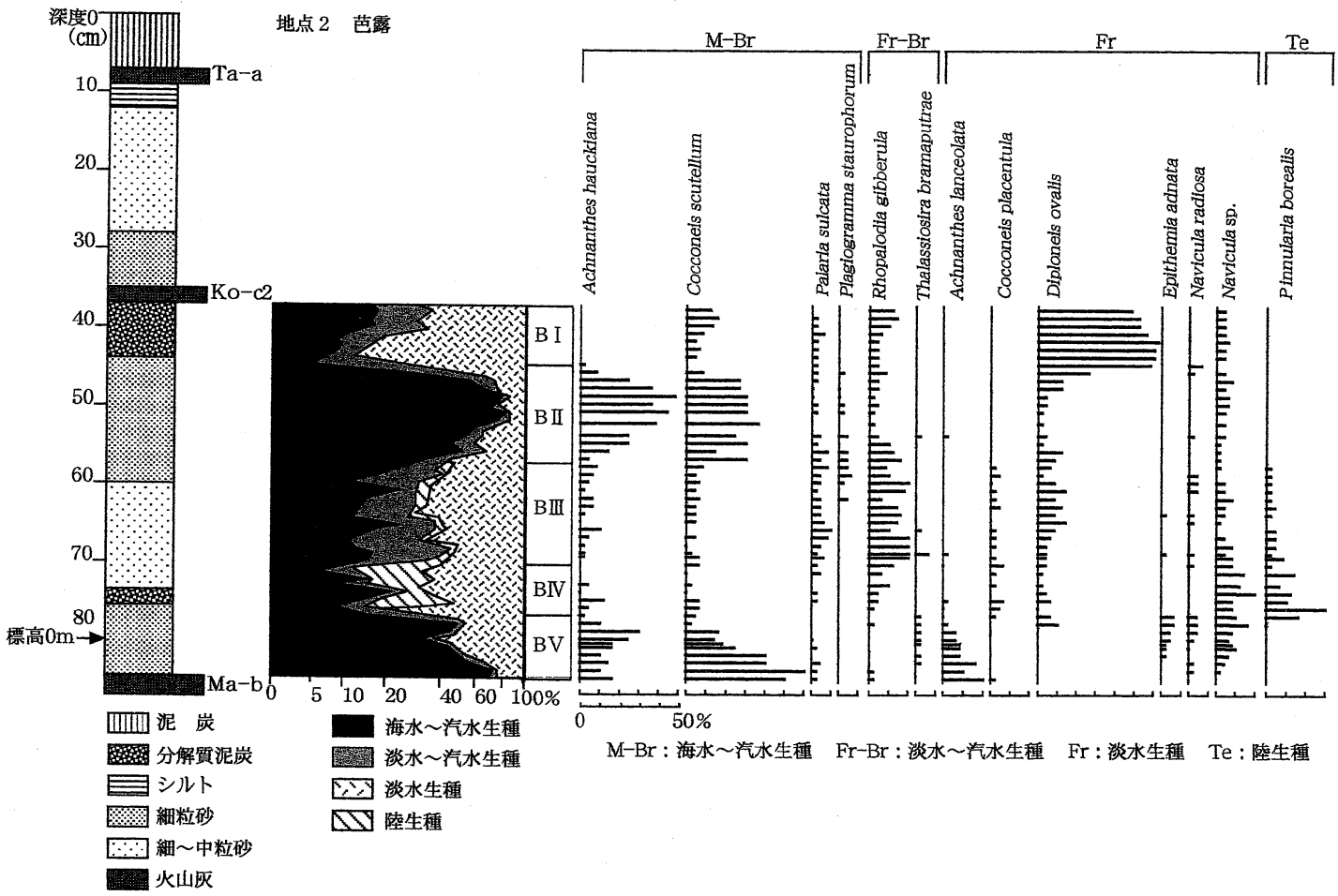

図 3 芭露(地点2)における地質柱状図と珪藻遺骸分析結果 
までの堆積物中における珪藻遺骸分析の結果は, 図 2, 図3に示した.

珪藻の同定・生態については, Patrick and Reimer (1966, 1975), 鹿島(1986, 1989，1996), Krammer and Lange-Bertalot(1986，1988，1991), 小杉(1988), 安藤 （1990)にしたがった. 陸生珪藻のそれについては, 伊 藤・堀内(1991)にしたがった.

両地点とも全般的に淡水生種が優占するが，海水～汽 水生種の出現比率と遺骸群集が示す環境から, 計呂地で 7つ, 芭露で $5 つ の$ 珪藻帯にそれぞれ区分した.

1. 計呂地 (地点 1)の分析結果 (図 2)

\section{K VII 帯(深度 $58 \sim 68 \mathrm{~cm}$ )}

Diploneis ovalis や Navicula radiosa などの淡水生種 が多くの層準で全体の約 70 80\%を占める. Rhopalodia gibberula や Thalassiosira bramaputrae などの淡水〜 汽水生種が，ほとんどの層準で全体の約 $10 \%$ 以上産出 する. Palaria sulcata や Cocconeis scutellum などの海 生〜汽水生種が，一部の層準を除いて全体の約 2 7\% 産出する. このことから, 淡水の影響が強かったが, や や海水の影響を受けていたと考えられる.

\section{K VI 帯 (深度 55 58 cm)}

淡水生種が卓越し, 特に Tabellaria fenestrata が優占 する. 淡水〜汽水生種むわずかながらみられるが，ほと んどの層準において全体の約 3\%しか産出しない．この ことから, 当時は海水の影響力溺まり, やや汽水の影響 を受けていたと考えられる.

\section{K V 帯 (深度 49 55 cm)}

Navicula radiosa や Nitzschia palea などの淡水生種 が卓越する. 淡水 汽水生種は, ほとんどの層準で全体 の約 $10 \%$ 未満であり, 深度 $53 \mathrm{~cm}$ より上位の層準では 全体の約 1\%程度しかみられない. 海水〜汽水生種は産 出しない.このことから，汽水の影響がわずかとなり， 淡水の影響が強くなったことが示唆される.

\section{K IV 帯 (深度 32 49 cm)}

淡水〜汽水生種や海水〜汽水生種の産出はみられな い. 淡水生種が卓越し，そのうち真流水性種の Meridion circulare が大部分の層準において全体の約 40〜50\%に 達することから, 流れのある淡水域へ移行したと推定さ れる.

\section{K III 帯 (深度 22 32 cm)}

淡水生種が卓越するが，淡水～汽水生種の Rhopalodia gibberula, Cyclotella meneghiniana, Thalassiosira bramaputrae, 海水〜汽水生種の Palaria sulcata, Cocconeis scutellum などが全体の約 5～15\% 産出する.
淡水〜汽水生種および海水〜汽水生種は保存状態が良い ことから，ほぼ現地性と考えられる．したがって，下位 の K IV帯に比へ，海水の影響が強くなったと考えられ る.

\section{K II 帯 (深度 13 22 cm)}

海水〜汽水生種は産出しない. 淡水〜汽水生種は, 多 くの層準で全体の 1\%程度しかみられない. 全体的に淡 水生種が卓越し，なかでむ Meridion circulare が多くの 層準で全体の約 $30 \%$ と優占することから，淡水の影響 が強い環境へ移行したことが考えられる.

\section{$\mathrm{K}$ I 帯 (深度 $10 \sim 13 \mathrm{~cm}$ )}

淡水生種と陸生種のみが産出する. 深度 $11 \mathrm{~cm}$ より上 位では, Hanztschia amphioxys などの陸生種が全体の 約 50〜60\% 産出する. したがって, Ko-c2 が堆積した頃 は，離水が進んでいたと考えられる。

\section{2. 芭露(地点 2)の分析結果(図 3)}

\section{B V 帯 (深度 77 85 cm)}

Achnanthes lanceolata, Epithemia adnata, Navicula radiosa などの淡水生種が大部分の層準で全体の約 45 25\% 産出する. これに対し, Cocconeis scutellum, Achnanthes hauckiana, Palaria sulcata などの海水〜 汽水生種が，全層準を通じて全体の約 40〜 70\%を占め る. また, Thalassiosira bramaputrae, Rhopalodia gibberula などの淡水〜汽水生種は, 多くの層準で全体の約 2 3\%みられる程度である.このことから，海水の影響 が強い環境下にあったと推定される。

\section{B IV 帯 (深度 70 77 cm)}

海水～汽水生種が，多くの層準から全体の約 10～20\% 産出するむのの, 下位の B V帯に比べて大きく減少し, 淡水生種は増加する。このことから, 淡水の影響加強く なったと推定される. 淡水〜汽水生種の Rhopalodia gibberula が多くの層準で約 5 10\%産出する. また, ほとんどの層準から, 陸生種の Pinnularia borealis が全 体の約 10～15\% 産出する.

B III 帯 (深度 $57 \sim 70 \mathrm{~cm}$ )

淡水生種がすべての層準を通じて全体の約 $60 \%$ 之卓 越する. また, Palaria sulcata や Achnanthes hauckiana などの海水〜汽水生種が，大部分の層準で全体の約 15〜25\%みられる. しかし, 下位の B IV 帯に比べると, 淡水〜汽水性種の Rhopalodia gibberula が増加し, ほ とんどの層準から全体の約 10２0\% 産出する. このこ とから，汽水の影響か強くなったと考えられる.

\section{B II 帯 (深度 44 57 cm)}

Achnanthes hauckiana, Cocconeis scutellum, Pala- 
ria sulcata, Plagiogramma staurophorum などの海水 〜汽水生種が高率で産出し，大部分の層準で全体の約 $50 \%$ 以上を占める. 淡水〜汽水生種は，ほとんどの層準 において全体の約 5〜15\% 産出するが, 下位の B III帯よ り減少する.ささに，淡水生種が多くの層準を通じて全 体の約 15～30\% しか産出しないことから，海水の影響 が強くなったと推定される.

\section{B I 帯 (深度 $37 \sim 44 \mathrm{~cm}$ )}

淡水生種が卓越し, 特にDiploneis ovalis が全体の 40 〜60\%を占める. ほかに, Navicula sp.などが産出す る. このことから, 淡水の影響強くなったと推定され る.

\section{IV. 考 察}

両地点における珪藻帯を対比するため, $\mathrm{Ma}-\mathrm{b}$ から Ko-c2 までの堆積速度を一定と仮定し, 各珪藻帯の暦年 代を算出した(図 4). この結果と各帯の珪藻遺骸出現傾 向から，ほぼ同時期に海水〜汽水生種が特徵的に出現ま たは増加する K VI帯と B V 帯, K III帯と B II 帯, 同種の 出現がみられない, または減少する K VI・K V・K IV帯 と B IV・B III帯，KII・K I 帯と B I 帯がそれぞれ対比 される(図 4).

これらのうち, 海水〜汽水生種に注目すると, それら が特徵的に出現または増加する $2 つ$ 層準(地点 1 の K VI帯およびK III帯，地点 2 の B V 帯および B II 帯)が
確認できる. 湖からの距離に差があることに起因して, 両調查地点での海水〜汽水生種の出現率は, 值そのもの はかなり異なるあのの, 層位的な出現パターンは似てい る. このような海水〜汽水生種の増減は, 周辺水域の塩 分濃度の変化を反映していると考えられるが，両地点で の共通した塩分濃度変化は, サロマ湖周辺で起こった海 水準変動に基づく海進・海退に起因している可能性が高 い. 両調查地点が直接海に面していないことから，塩分 濃度変化が海水準変動に起因していない可能性屯ある が，後述のように塩分濃度の上昇・低下期が，それぞれ 気候の温暖期・寒冷期に一致することから，海水準变動 が原因になっているとみて矛盾しない．

以下に, Ma-b から Ko-c2 までを 4つの時期に分け， それぞれの珪藻帯が示す環境亡海進・海退および古環境 との関連について考察する.

1. 10 世紀末〜11 世紀

B V 帯および K VII帯では, それらの上位の珪藻帯に比 べて海水の影響が強いことから，この時期には海進があ り，その影響は河口から約 $500 \mathrm{~m}$ 上流の地点 1 まで及ん だことがうかがえる. 平井(1994)は，サロマ湖岸(おむに 東部域ににおいて，10 世紀頃の高海水準期に形成された 湖岸段丘が存在するとしており，今回の分析結果はこれ と調和的である. また, 赤松ほか(1998)は, 当時の年平 均気温が現在より約 $2^{\circ} \mathrm{C}$ 高温であったとしており, こ の海進が温暖化に伴う現象であることを示唆している.

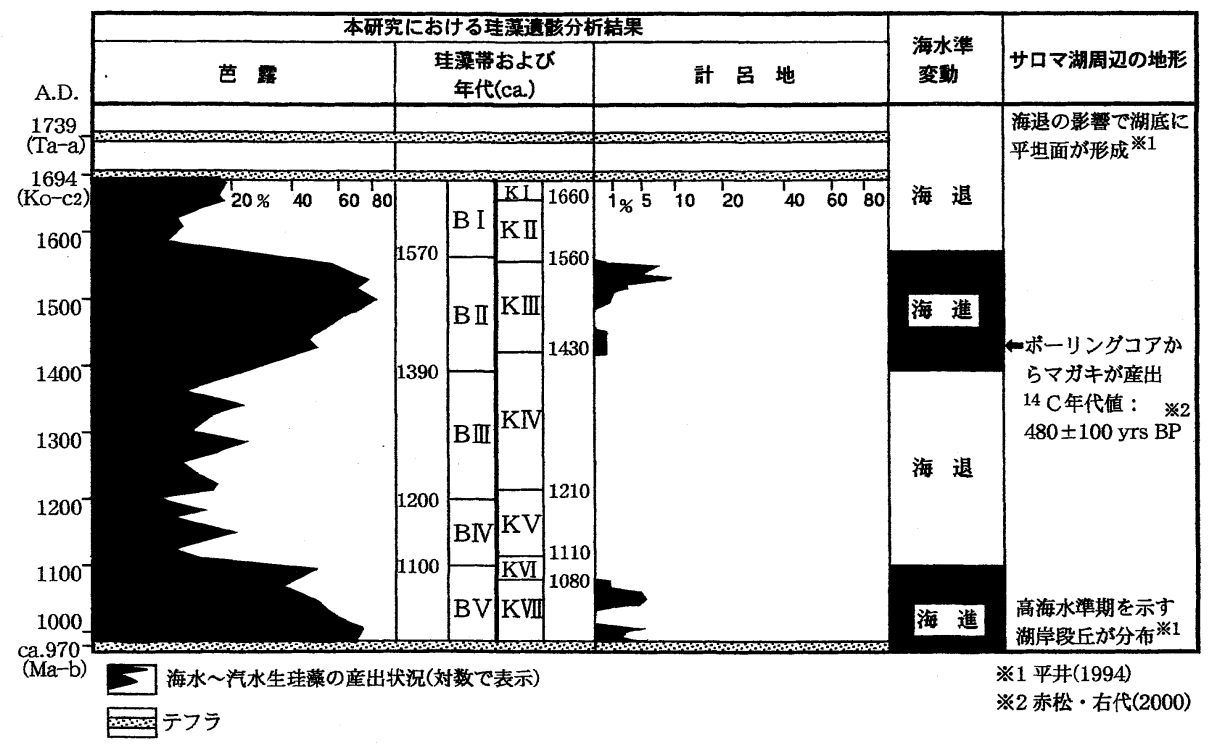

図 4 サロマ湖周辺域における 10〜 17 世紀の海水準变動 
これは, Hughes and Diaz(1994)の中世温暖期(Medieval Warm Period)の一部に相当する可能性がある.

\section{12 世紀 14 世紀末}

$\mathrm{K} \mathrm{VI} \cdot \mathrm{K} \mathrm{V} ・ \mathrm{~K} \mathrm{I}$ 帯と B IV ・ B II 帯では, それらの上 下の珪藻帯に比へて淡水の影響が強いことから, この時 期に海退が生じたと考えられる. 特に, 地点 1 では海退 によって河口が後退し, 河川水の影響をより強く受けた 可能性がある. この時期は, 福井県水月湖の縞状堆積構 造から Fukusawa (1995)が求めた寒冷期 (A.D. 1080 1350) とほぼ一致する.

\section{14 世紀末 16 世紀末}

K III帯之 B II 帯では, 上下の珪藻帯に比べて海水の影 響が強くみられ，この時期に海進が起こったと考えられ る. この時期は, Fukusawa(1995)が求めた温暖期(A.D. 1350〜1580) とほぼ一致し，またサロマ湖キムアネップ 崎におけるボーリングコアから産出した温暖水系貝類の ${ }^{14} \mathrm{C}$ 年代值が $480 \pm 100 \mathrm{yrs} \mathrm{BP}$ と報告されている(赤松. 右代, 2000)ことから, 気候温暖期に対応していると考え られる.

\section{16 世紀末 17 世紀}

K II ・ K I 帯と B I 帯では, 下位の珪藻帯と比へ淡水 の影響が強く, 海退があったと考えられる. 特に, 地点 1 では 17 世紀末頃に, 海退によって離水が進んだ可能性 がある. この時期に形成された地形として, 平井 (1994) はサロマ湖の湖底に約 300 年前の低海水準期にできた平 坦面が存在することや, 網走湖北西岸において現水位よ り下位に約 300 年前に堆積した泥炭が分布することなど を報告している. 16〜19 世紀までの約 300 年間は, ヨー ロッパを中心として世界的に寒冷であった時代で小水期 (Little Ice Age) と呼ばれ, 年平均気温は現在より約 $1^{\circ} \mathrm{C}$ 低汃たと推定されている(三上，1991). また，Fukusawa(1995)はA.D. 1580～1880を寒冷期としている. 16 世紀末〜 17 世紀という時期はこれらの寒冷期に含まれ る.

以上のような本研究で明らかとなった塩分濃度の上 昇・低下, すなわち完新世における相対的な海水準変動 の要因としては, 気候変動のほかハイドロアイソスタ シー(Maeda et al., 1992 ; 前田ほか, 1994 ; 沢井・三塩, 1998)や局所的な地款变動が考えられ, 本研究における 分析結果が, サロマ湖周辺域にだけみられる固有な現象 である可能性あある. また, 堆積物中には, 津波などに よる一時的な海水の流入か記録されることあある. しか し, 本研究で明らかとなった塩分濃度の上昇期と下降 期, すなわち海進期と海退期は既往研究で明らかにされ
た気候の温暖期と寒冷期にそれぞれよく一致している. したがって, これらの海水準変動は, 気候変動を反映し たものである可能性が高い.

ただし, 気候変動以外の要因を否定する明確な証拠が あるわけではないので, 今後はより広域なデー夕の収 集・比較を行い, 本研究によって得られた塩分濃度変化 の要因について, さらに検討していく必要がある.

謝辞 本研究を進めるにあたり, 北海道大学大学院理 学研究科岩田圭示博士, 苫小牧市博物館荒川忠宏主任学 芸員, 中川町郷土資料館疋田吉識研究員には多くの貴重 なご指導・ご助言をいただいた. 北海道大学大学院理学 研究科田島貴裕技官には火山灰の分析をしていただい た. 石狩市教育委員会文化財 - 博物館開設準備室志賀健 司学芸員, 財団法人バイオインダストリー協会塩野正道 博士には, 珪藻の生態や分類について多くのご指導をい ただいた．以上の方々に厚く御礼申し上げる.

\section{引用文 献}

赤松守雄・右代啓視（1995）オホーツク文化遺跡の立地 とその背景. 北の歴史・文化交流研究事業研究報告, 19-44, 北海道開拓記念館.

赤松守雄・右代啓視 (2000) 北方諸地域における 10 世紀 以降の温暖期の存在とその意義. 北の文化交流史研究 事業研究報告, 3-14, 北海道開拓記念館.

赤松守雄 - 石橋孝夫 - 斉藤文紀 - 山田悟郎 - 右代啓視

（1998）北方諸地域における歴史時代の環境復元. 北の 文化交流史研究事業中間報告, 153-162, 北海道開拓記 念館.

安藤一男（1990）淡水産珪藻による環境指標種群の設定 と古環境復元への応用. 東北地理，42，73-88.

遠藤邦彦・隅田まり・宇野リべカ（1989）北海道東部の 完新世後期テフラ層序とその給源火山. 地学雑誌, 98 , 506-510.

遠藤邦彦・隅田まり・宇野りべ力（1996a）北海道東部, オホーツク海沿岸に分布するトコロ（常呂）火山灰. 日本第四紀学会編「第四紀露頭集一日本のテフラ」: 104-104.

遠藤邦彦・鈴木正章・藤井 亨 (1996b) 渡島半島西岸 の海岸砂丘とテフラ. 日本第四紀学会編「第四紀露頭 集一日本のテフラ」: 135-135.

Fukusawa, H. (1995) High-resolusion reconstruction of environmental changes from the last 2,000 years varved sediments in Lake Suigetsu, central Japan. 
Mikami, T., Matsumoto, E., Ohta, S. and Sweda, T. (eds.) Paleoclimate and environmental variability in Austral -Asian transect during the past 2000 years : 84-89, Nagoya University.

福澤仁之・塚本すみ子・塚本 斉・池田まゆみ・岡村

真・松岡裕美 (1998) 年縞堆積物を用いた白頭山-苫小 牧火山灰 (B-Tm) の降灰年代の推定. LAGUNA，5, 55-62.

早川由紀夫・小山真人 (1998) 日本海をはさんで 10 世紀 に相次いで起こった二つの大噴火の年月日一十和田湖 之白頭山一. 火山, 43, 403-407.

平井幸弘（1987）サロマ湖の湖岸・湖底地形と完新世後 半の才ホーツク海の海水準変動. 東北地理, 39, 1-15. 平井幸弘 (1994) 自然の景観に恵まれたサロマ湖. 地理,

39-9, 89-95.

Hughes, M.K. and Diaz, H.F. (1994) Was there "Medieval Warm Period", and if so, where and when? Climatic Change, 26, 109-142.

磯部一洋・佐藤卓見・横田節哉・羽坂俊一 (1999) 北海 道オホーツク海沿岸に連なる海跡湖を訪ねて(続). 地 質ニュース，540，55-69.

伊藤吉永・堀内誠示 (1991) 陸生珪藻の現在に於ける分 布之古環境解析への応用. Diatom， 6, 23-44.

鹿島 薰（1986）沖積層中の珪藻遺骸群集の推移と完新 世の古環境変遷. 地理学評論, 59, 383-403.

鹿島 薫 (1989) 鹿児島県上㽀島汽水生湖沼群における 珪藻の分布特性と珪藻殼の堆積過程. 日本ベントス研 究会誌, $35 / 36,29-40$.

鹿島 薰（1996）網走湖・サロマ湖の湖底堆積物から得 られた珪藻遺骸群集. LAGUNA，3，33-39.

勝井義雄（1996）摩周火山灰層. 地学団体研究会編「新 版地学事典」: 1255-1255, 平凡社.

児平英司 (1996) 完新世における斜里地域の古環境復元. 知床博物館研究報告, 17, 1-16.

小杉正人（1988）珪藻の環境指標種群の設定と古環境復 元への応用. 第四紀研究，27，1-20.

Krammer, K. and Lange-Bertalot, H. (1986) Bacillariophyceae Teil 1. Susswasserflora von Mitteleeuropa.
876 p, Gustav Fisher Verlag.

Krammer, K. and Lange-Bertalot, H. (1988) Bacillariophyceae Teil 2. Susswasserflora von Mitteleeuropa. 596 p, Gustav Fisher Verlag.

Krammer, K. and Lange-Bertalot, H. (1991) Bacillariophyceae Teil 3. Susswasserflora von Mitteleeuropa. 576 p, Gustav Fisher Verlag.

町田 洋（1996）泥炭地における最近 1,000 年間のテフ ラークッチャロカルデラ美留和一. 日本第四紀学会編 「第四紀露頭集一日本のテフラ」: 109-109.

町田 洋・奥村晃史・山縣耕太郎（1994）テフラ研究委 員会野外集会-北海道 (石狩一十勝一道東)のテフロ クロノロジー案内書. $70 \mathrm{p}$, 第四紀学会テフラ研究委 員会.

Maeda, Y., Nakada, M., Matsumoto, E. and Matsuda, I. (1992) Crustal tilting derived from Holocene sealevel observations along the east coast of Hokkaido in Japan and upper mantle rheology. Geophysical Res Let., 19, 857-860.

前田保夫 - 松田 功 - 中田正夫 - 松島義章 - 松本英二 （1994）完新世における北海道オホーツク沿岸域の海 面変化一海面高度の観察値己理論值について一. 山形 大学紀要 (自然科学), 13,205-229.

三上岳彦（1991）小水期-気候の数百年变動．科学，61, 681-688.

Patrick, R. and Reimer, C.W. (1966) The diatom of the United States, $1.688 \mathrm{p}$, Acad. Nat. Sci.

Patrick, R. and Reimer, C.W. (1975) The diatom of the United States, 2. 213 p, Acad. Nat. Sci.

沢井祐紀・塩和歌子（1998）北海道東部厚岸湿原にお ける過去 3,000 年間の海進・海退. 第四紀研究, 37,1 -12 .

嶋田智恵子・村山雅史・青木かおり ・ 中村敏夫 ·長谷川 四郎・大場忠道（2000）珪藻分析に基づく南西オホー ック海の完新世古海洋環境復元. 第四紀研究, 39, 439 -449 .

徳井由美（1995）徳井由美業績集. $309 p$, 徳井由美業績 集刊行会. 


\title{
Sea-level Change from the 10 th to 17 th Centuries around Lake Saroma, Eastern Hokkaido
}

\author{
Yuhji Soeda* and Morio Akamatsu*
}

Eastern Hokkaido is known to be the area where marker tephras for the historic ages are widely distributed. The authors analyzed the diatoms in the sediments which are intercalated between the tephras of $\mathrm{Ma}-\mathrm{b}$ (Mashu-b volcanic ash erupted ca. 970) and $\mathrm{Ko}^{-} \mathrm{c} 2$ (Komagadake-c2 volcanic ash erupted in 1694), and tried to reconstruct the paleoenvironment of this area. The two peaks of marine and brackish diatoms suggest the two stages of high salinity (late 10 th -11 th century and late 14 th - late 16 th century). Such salinity changes during the period from the 10 th to 17 th centuries seem to be phenomena corresponding to the cycles of transgression and regression that accompanied climatic changes.

* The Historical Museum of Hokkaido. 53-2 Konopporo Atsubetsu-cho, Atsubetsu-ku, Sapporo, 004-0006, Japan. E-mail : 